\title{
The Effects of EI Nino on Agricultural GDP of Ethiopia
}

\author{
Melkamu Belina Negeri \\ Department of Economics, Wollega University, Nekemte, Ethiopia
}

Email address:

melkizan@yahoo.com

\section{To cite this article:}

Melkamu Belina Negeri. The Effects of El Nino on Agricultural GDP of Ethiopia. American Journal of Water Science and Engineering. Vol. 3, No. 4, 2017, pp. 45-49. doi: 10.11648/j.ajwse.20170304.11

Received: August 16, 2017; Accepted: September 8, 2017; Published: October 10, 2017

\begin{abstract}
End hunger, achieve food security and improve nutrition is at the heart of the sustainable development goals. At the same time, climate change is already impacting agriculture and making the challenge even more difficult. In many parts of the world, much of the year-to-year variation in climate is traced to the El Nino episode. This paper uses El Nino Southern Oscillation (ENSO) index to examine the effect of El Nino shock on agricultural GDP of Ethiopia. The paper employed Vector Autoregressive (VAR) model in analysing 26 years time series data. Before regressing the data, activities such as lag selection, unit root test, Johansen Cointegration test, and diagnostics test were done. The result of the study shows that an incidence of El Nino phenomena truncate agricultural GDP of Ethiopia by 13.59 percent. The result is statistically significant at less than 5 percent significant level. And also 92.66 percent of the total variation in the model is explained by the explanatory variables. Thus the nation should work hard in adoption of water harvesting technology, irrigation, drought resistance and perennial crops to mitigate the consequence of El Nino shock.
\end{abstract}

Keywords: El Nino, Ethiopia, Agriculture, GDP, VAR

\section{Introduction}

End hunger, achieve food security and improve nutrition is at the heart of the sustainable development goals. At the same time, climate change is already impacting agriculture and making the challenge of ending hunger and malnutrition even more difficult. While some of the problems associated with climate change are emerging gradually, action is urgently needed now in order to allow enough time to build resilience into agricultural production systems [3].

In many parts of the world, much of the year-to-year variation in climate can be traced to the El Nino episode [9]. The connection between Earth's oceans and atmosphere has a direct impact on the weather and climate conditions we experience. El Niño and La Niña, together called the El Niño Southern Oscillation (ENSO), are periodic departures from expected sea surface temperatures (SSTs) in the equatorial Pacific Ocean [6]. El Nino and La Nina are amongst the most powerful phenomena on Earth, affecting the climate across more than half the planet. El Niño (Spanish name for a male child) is used to refer to a weak, warm current appearing annually around Christmas along the coast of Ecuador and Peru. El Niño events occur every three to seven years and may last from 12 to 18 months. In contrast to El Niño, La
Niña (female child) refers to an anomaly of unusually cold sea surface temperatures found in the eastern tropical Pacific. ENSO measures the intensity of El Nino and La Nina [8].

Ethiopia is one of the countries most affected by the El Niño phenomenon, millions of Ethiopians have lost their source of food, water and livelihoods. The country's Afar, Somali and Oromia regions have been particularly hard hit. Water sources have dried up, pastoralists no longer find pasture for their animals and between 50\% and 90\% of crops have failed. The loss of animals, a source of milk and protein, is having a negative effect on the nutritional status of children. Malnutrition and diseases such as scabies and diarrhoea are on the increase as a result of water shortage [1].

Similarly, the WFP [11] report shows that as a result of El Nino shock, crop production in Ethiopia dropped by 50 to 90 percent in some regions, failed completely in the eastern part of the country, and access to pasture and water deteriorated until the start of the next rainy season. And also, the lack of rainfall and subsequent drought have led to the inflation of food prices. In a nation like Ethiopia where an economy highly depends on the performance of agriculture, an El Nino shock have a profound impact on the nation's economy. Hence, by considering the paramount importance of assessing the effect of El Nino at national level, the paper 
tries to measure the effect of El Nino shock on agricultural GDP of Ethiopia.

\section{Methodology}

\subsection{Description of the Study Area}

Ethiopia is the ninth largest country in Africa with total land area of 1.1 million square kilometers. As a landlocked country, Ethiopia is bound to the east by Djibouti and Somalia, to the north and northeast by Eritrea, to the south by Kenya and to the west by the Sudan. Ethiopia is a country of great geographical diversity. Located within the tropics, its physical conditions and variations in altitude have resulted in great range of terrain, climate, soil, flora and fauna. Its altitude ranges from the highest peak at Ras Dashen $(4,620 \mathrm{~m}$ asl) down to the Dalol depression(148m below sea level) [2]. Ethiopia's economy depends heavily on the agricultural sector which contributes over $36.7 \%$ of Gross Domestic Product and $77.4 \%$ of exports [7].

\subsection{Source of Data}

The study used a time series data from the year 1990 to 2015. Agricultural GDP data and data for computing agricultural labor productivity were gathered from the databases of the World Bank [10] while El Nino southern Oscillation anomaly data were taken from the National Oceanic and Atmospheric Administration (NOAA) Nino 3.4 index.

\subsection{Method of Data Analysis}

In economic research involving time series data, before any kind of statistical estimation takes place, the data of all variables in the model have to be tested for their stationarity. A stochastic process is said to be stationary if its mean and variance are constant over time and the value of the covariance between the two periods depends only on the distance or gap or lag between the two time periods and not the actual at which the covariance is computed. If a time series is non stationary, we can study its behavior only for the time period under consideration [4]. There are various statistical tests in the detection of non-stationarity or unit root problem. This study used the Augmented Dickey-Fuller (ADF) test for undertaking the stationary test. The ADF test consists of estimating the following regression:

$$
\Delta Y_{t}=\beta_{1}+\beta_{2} t+\delta Y_{t-1}+\sum_{i=1}^{m} \alpha_{i} \Delta Y_{t-i}+\varepsilon_{t}
$$

where $\varepsilon_{t}$ is a pure white noise error term and where $\Delta Y_{t-i}=\left(Y_{t-1}-Y_{t-2}\right), \Delta Y_{t-2}=\left(Y_{t-2}-Y_{t-3}\right), \ldots$ etc. To allow for the various possibilities, the ADF test is estimated in three different forms, that is, under three different null hypotheses as follows;
$Y_{t}$ is a random Walk: $\Delta Y_{t}=\delta Y_{t-1}+u_{t}$

$Y_{t}$ is a random Walk with drift: $\Delta Y_{t}=\beta_{1}+\delta Y_{t-1}+u_{t}$

$Y_{t}$ is a random Walk with drift around a stochastic trend: $\Delta Y_{t}=\beta_{1}+\beta_{2} t+\delta Y_{t-1}+u_{t}$

Before estimating a Vector Autoregressive (VAR) model, the study determined the optimal lag length of the VAR model using the Akaike Information Criteria (AIC) and Swartz Information Criteria (SIC). This two criteria has been proven as superior to other tests in most empirical studies. According to the AIC and SIC tests, the VAR estimates with the lowest values are the most efficient one.

After selecting the optimal lag length for the VAR model, and undertaking the Johansen Cointegration test, the study selected the appropriate VAR model. When the trace statistic value is greater than the critical value, its shows that there is cointegration between the variables thus Vector Error-Correction (VECM) model rather than the Unrestricted VAR model will be used and vise versa. By running the VECM/Unrestricted VAR model, and applying the Granger causality test, the study checks the kind of causality running as a whole from El Nino and agricultural labor productivity to agricultural GDP of Ethiopia. Finaly, to check whether the model as a whole is good or not, the study made a diagnostic test such as Lagrange-multiplier test and Jarque-Bera test.

Following Maryam [5], the regression equation were estimated to analyse the effect of El Nino on Agricultural GDP of Ethiopia. In the estimated equation, Agricultural GDP of Ethiopia is a function of El Nino southern oscillation and agricultural labour productivity. The equation is as follow;

$$
y_{t}=\beta_{o}+\beta_{1} \mu_{t}+\beta_{2} v_{t}+\varepsilon_{t}
$$

Where $y_{t}$ represents the natural logarithm of agricultural GDP of Ethiopia at time $\mathrm{t}$, and $v_{t} \sim \mathrm{iid}\left(0, \sigma_{\mathrm{v}}\right)$ is the El Nino shock. $\mu_{t}$ is the deterministic trend component, which controls for technological advances in agricultural production over time, and also a possible effect of global climate change, if any.

\section{Result and Discussion}

The paper first present the result of Augmented DickeyFuller unit root test. Appendix 1 shows that the variables agricultural GDP, ENSO, and agricultural labor productivities were initially non stationary, after first differencing the variables become stationary(Appendix 2).

Before estimating the appropriate VAR model, 1 (Appendix 3) were selected as the optimal lag length based on the lag selection criteria of the AIC and SIC. Using the Johansen Cointegration test, the study selected the Unrestricted VAR model as the trace statistic and max statistic value were less than the critical value, evidencing the non existance of cointegration between the variables. 
Table 1. Johansen Test for Cointegration.

\begin{tabular}{|c|c|c|c|c|c|}
\hline & \multirow{2}{*}{$\begin{array}{l}\text { Number of obs }=25 \\
\text { Lags }=1\end{array}$} \\
\hline Sample: 1991-2015 & & & & & \\
\hline & & & & & $5 \%$ \\
\hline maximum & & & & trace & critical \\
\hline rank & parms & LL & eigenvalue & statistic & value \\
\hline 0 & 3 & 56.254058 & . & $20.8638 *$ & 29.68 \\
\hline 1 & 8 & 61.988355 & 0.36792 & 9.3952 & 15.41 \\
\hline 2 & 11 & 66.34148 & 0.29408 & 0.6890 & 3.76 \\
\hline 3 & 12 & 66.68596 & 0.02718 & & \\
\hline maximum & & & & $\max$ & critical \\
\hline rank & parms & LL & eigenvalue & statistic & value \\
\hline 0 & 3 & 56.254058 & & 11.4686 & 20.97 \\
\hline 1 & 8 & 61.988355 & 0.36792 & 8.7063 & 14.07 \\
\hline 2 & 11 & 66.34148 & 0.29408 & 0.6890 & 3.76 \\
\hline 3 & 12 & 66.68596 & 0.02718 & & \\
\hline
\end{tabular}

*trace statistic is less than critical value.

Running the Unrestricted VAR model (Appendix 4), and applying the Granger causality test (Appendix 5), the study found that there was a short run causality running as a whole from El Nino and agricultural labor productivity to agricultural GDP of Ethiopia at less than 5 percent.

By making a diagnostic test of Lagrange-multiplier test (Appendix 6), the study checked that there were no problem of autocorrelation and by Jarque-Bera test (Appendix 7), the study found that residuals were normally distributed evidencing desirable properties.

After undertaking all the necessary tests, the study used Ordinary Least Square (OLS) method for estimating coefficients of the regression equation. Table 2 bellow illustrates the result of the regression;

Table 2. OLS Regression Result.

\begin{tabular}{|c|c|c|c|c|c|c|}
\hline Source & ss & df & Ms & \multicolumn{3}{|c|}{ Number of obs $=26$} \\
\hline Model & 10.4478117 & 2 & 5.22390583 & \multicolumn{3}{|c|}{$\mathrm{F}(2,23)=145.16$} \\
\hline Residual & .827693437 & 23 & .035986671 & \multicolumn{3}{|c|}{ Prob $>F=0.0000$} \\
\hline Total & 11.2755051 & 25 & .451020204 & \multicolumn{3}{|c|}{$\begin{array}{l}\text { R-squared }=0.0000 \\
\text { Adj R-squared }=0.9202 \\
\text { Root MSE }=1897\end{array}$} \\
\hline LnAgrGDP & Coef. & Std. Err. & $\mathrm{t}$ & $\mathrm{P}>|\mathrm{t}|$ & \multicolumn{2}{|c|}{ [95\% Conf. Interval] } \\
\hline EINino & -.1359002 & .0614172 & -2.21 & 0.037 & -2629514 & -.0088489 \\
\hline AgrLabourP & 7.197576 & .4224964 & 17.04 & 0.000 & 6.323576 & 8.071577 \\
\hline cons & 21.30783 & .0996014 & 213.93 & 0.000 & 21.10179 & 21.51387 \\
\hline
\end{tabular}

Source: (Own computution, 2017, using WB and NOAA data)

The result of the regression in the table 2 above shows that an incidence of El Nino phenomena truncate agricultural GDP of Ethiopia by 13.59 percent. The result is statistically significant at less than 5 percent significant level. And also 92.66 percent of the total variation in agricultutal GDP of Ethiopia in the regression model were explained by El Nino and agricultural labor productivity.

\section{Conclusion}

By using ENSO index, the paper examined the effect of El Nino shock on agricultural GDP of Ethiopia. In attaining the aim of the paper, the study used 26 years time series data gathered from the WB and NOAA. Before regressing the data, activities such as lag selection, unit root test, Johansen Cointegration test, and diagnostics test were done. Based on the Johansen Cointegration test, the study selected the Unrestricted VAR model. Finally, after undertaking all the necessary tests, the result of the OLS regression shows that an incidence of El Nino truncated agricultural GDP of Ethiopia by 13.59 percent. The result were statistically significant at less than 5 percent significant level. And also 92.66 percent of the total variation in the model were explained by El Nino and agricultural labor productivity.

\section{Recommendation}

The study indicate that incidence of El Nino shock significantly affect agricultural GDP of Ethiopia. Thus, to mitigate the consequence of El Nino shock, the nation should work hard in adoption of water harvesting technology, promotion of irrigation, afforestation of mountains, cultivation of drought resistance and perennial crops, put atmost effort on the current undergoing soil and water conservation techniques, and use appropriate and timely information on future El Nino. 


\section{Appendix}

Appendix 1. Dicky-Fuller Test for Unit Root at Level_Non Stationary

\begin{tabular}{llll}
\hline Variable & With Intercept & With Trend & None \\
\hline LnAgricultural GDP & 0.559 & -1.276 & 1.450 \\
ENSO & -2.395 & -2.031 & -1.564 \\
Agricultural Labor Pr & -0.423 & -1.452 & 0.341 \\
\hline
\end{tabular}

Appendix 2. Dicky-Fuller Test for Unit Root After First Differencing _ Stationary

\begin{tabular}{lll}
\hline Variable & With Intercept & With Trend \\
\hline LnAgricultural GDP & -3.034 & -4.458 \\
ENSO & -3.740 & -4.033 \\
Agricultural Labor Pr & -3.509 & -5.067 \\
\hline
\end{tabular}

\section{Appendix 3. Optimal Lag Length}

\begin{tabular}{|c|c|c|c|c|c|c|c|c|}
\hline \multicolumn{6}{|c|}{ Sample: 1993 - 2015} & \multicolumn{3}{|c|}{ Number of obs $=23$} \\
\hline \multicolumn{9}{|c|}{ Selection-order criteria } \\
\hline lag & LL & LR & $\mathrm{df}$ & $\mathrm{p}$ & FPE & AIC & HQIC & SBIC \\
\hline 0 & 14.7531 & & & & .000072 & -1.02201 & -.984759 & -.8739 \\
\hline 1 & 66.334 & 103.16 & 9 & 0.000 & $1.8 \mathrm{e}-06^{*}$ & -4.72469 & $-4.5757^{*}$ & $-4.13226^{*}$ \\
\hline 2 & 72.3229 & 11.978 & 9 & 0.215 & $2.5 \mathrm{e}-06$ & -4.46286 & -4.20212 & -3.4261 \\
\hline 3 & 85.3271 & $26.008 *$ & 9 & 0.002 & $2.0 \mathrm{e}-06$ & $-4.81105^{*}$ & -4.43856 & -3.32997 \\
\hline
\end{tabular}

Endogenous: LnAgrGDP ElNino AgrLabourP

Exogenous:_cons

\section{Appendix 4. Vector Autoregression Result}

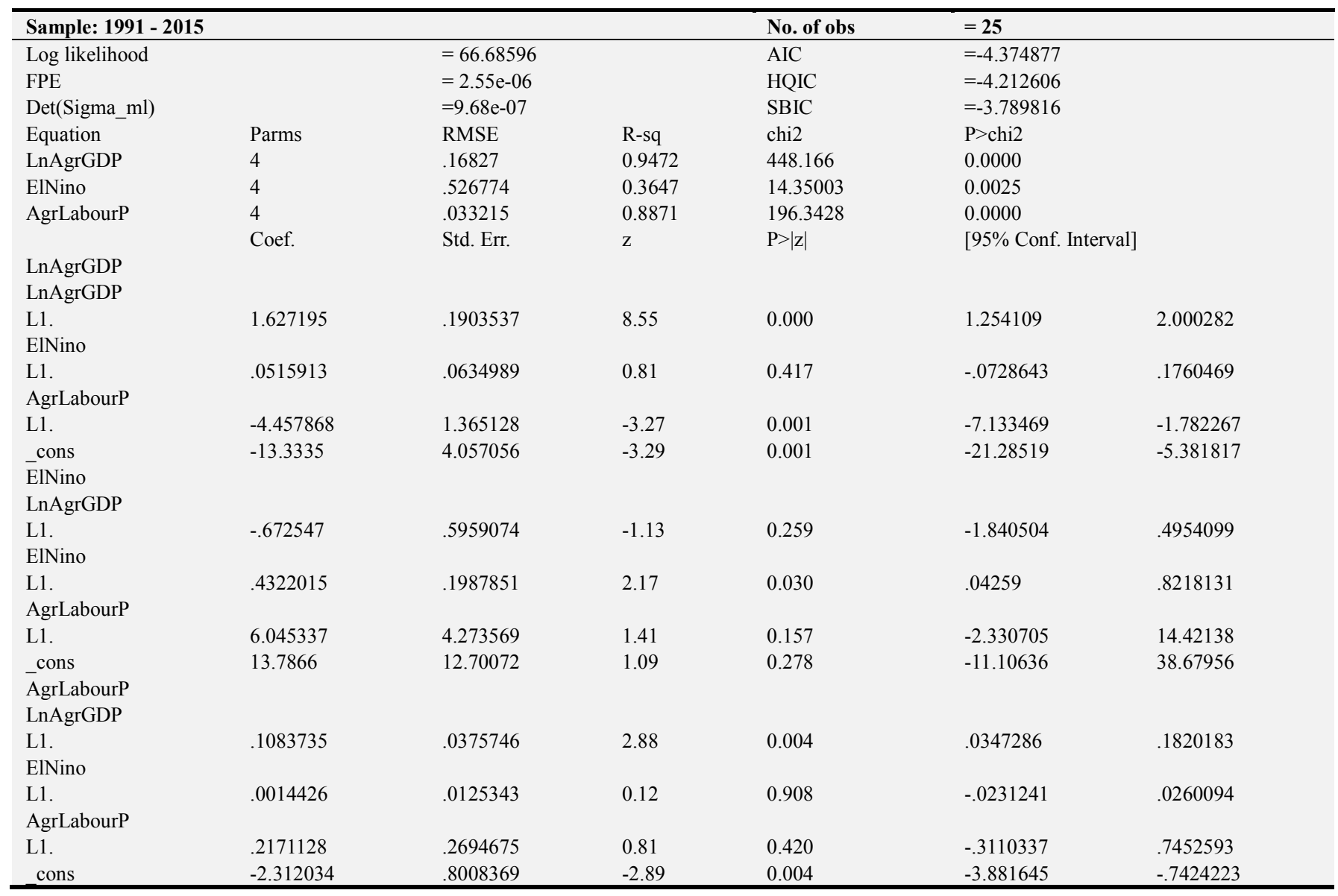


Appendix 5. Granger Causality Wald Test

\begin{tabular}{lllll}
\hline Equation & Excluded & chi2 & df & Prob>chi2 \\
\hline LnAgrGDP & ElNino & .66012 & 1 & 0.417 \\
LnAgrGDP & AgrLabourP & 10.664 & 1 & 0.001 \\
LnAgrGDP & ALL & 11.933 & 2 & 0.003 \\
ElNino & LnAgrGDP & 1.2738 & 1 & 0.259 \\
ElNino & AgrLabourP & 2.0011 & 1 & 0.157 \\
ElNino & ALL & 2.8091 & 2 & 0.245 \\
AgrLabourP & LnAgrGDP & 8.3187 & 1 & 0.004 \\
AgrLabourP & ElNino & .01325 & 1 & 0.908 \\
AgrLabourP & ALL & 11.432 & 2 & 0.003 \\
\hline
\end{tabular}

\section{Appendix 6. Lagrange-multiplier Test}

\begin{tabular}{llll}
\hline lag & chi2 & df & Prob $>$ chi2 \\
\hline 1 & 8.0776 & 9 & 0.52635 \\
2 & 8.9091 & 9 & 0.44571 \\
\hline
\end{tabular}

H0: no autocorrelation at lag order

\section{Appendix 7. Jarque-Bera Test}

\begin{tabular}{llll}
\hline Equation & chi2 & df & Prob $>$ chi2 \\
\hline LnAgrGDP & 0.342 & 2 & 0.84293 \\
ElNino & 1.065 & 2 & 0.58706 \\
AgrLabourP & 0.190 & 2 & 0.90935 \\
ALL & 1.597 & 6 & 0.95279 \\
\hline
\end{tabular}

\section{References}

[1] EC, 2016. Humanitarian Aid and Civil Protection, ECHO Factsheet - Ethiopia.

[2] EO(Ethiopia Overview), 2017. Ethiopian Goverment Portal found in http://www.ethiopia.gov.et

[3] FAO, 2016. Climate change and food security: Risks and Responses.

[4] Gujarati, 2004. Basic Econometrics, Fourth Edition, The McGraw-Hill Companies.

[5] Maryam Abdolrahimi, 2016. The Effect of El Niño Southern Oscillation (ENSO) on World Cereal Production, A thesis submitted in partial fulfilment of requirements for the degree of Master of Philosophy in the Faculty of Agriculture and Environment at The University of Sydney.
[6] National Oceanic Atmospheric Administration (NOAA). 2017. Earth System Research Laboratory, El Niño Southern Oscillation (ENSO). Available at http:// https://www.esrl.noaa.gov/psd/enso/

[7] NBE, 2016, National Bank of Ethiopia Annual Report, Addis Ababa, Ethiopia.

[8] Nelson Thornes, 2008. Impacts of El Niño and La Niña, Geofile Online.

[9] Richard M. Adams, Chi-Chung Chen, Bruce A. Mc Carl, and Rodney F. Weiher, 2010. The economic consequences of ENSO events for agriculture, CLIMATERESEARCH Clim Res. Vol. 13: 165-172, 1999.

[10] The World Bank, Data. Available at http://data.worldbank.org/indicator/NV.AGR.TOTL.ZS

[11] World Food Programme, 2016. WFP El Niño 2015-2016 Preparedness and Response, Situation Report \#2. 